\title{
Potential Evaluation and Basin Modeling of the Pabdeh Formation in Zagros Basin: A Case Study
}

\author{
Hossein Tabatabaei \\ Department of Petroleum Engineering, Gachsaran Branch, Islamic Azad University, Gachsaran, Iran \\ Email: Hossein_Tabatabaei@iaug.ac.ir
}

How to cite this paper: Tabatabaei, $\mathrm{H}$. (2017) Potential Evaluation and Basin Modeling of the Pabdeh Formation in Zagros Basin: A Case Study. Open Journal of Geology, 7, 505-516. https://doi.org/10.4236/ojg.2017.74035

Received: March 6, 2017

Accepted: April 27, 2017

Published: April 30, 2017

Copyright $\odot 2017$ by author and Scientific Research Publishing Inc. This work is licensed under the Creative Commons Attribution International License (CC BY 4.0).

http://creativecommons.org/licenses/by/4.0/ (c) (i) Open Access

\begin{abstract}
Pabdeh Formation is one of the most important source rocks in Zagros basin. In this study, thermal modeling and comparing of hydrocarbon potential evaluation of Pabdeh Formation in Mish Anticline and Gachsaran oil field have been investigated. For this reason, Rock-Eval pyrolysis was carried out on 21 cuttings samples collected from 2 boreholes (Well No. 55 and 83) of Gachsaran oil field and outcrop of Mish anticline. Accordingly, the Kerogen types of Pabdeh Formation in Gachsaran oil field are II, but in Mish anticline are type II and III. The amount of inert organic carbon determined for the Pabdeh Formation in Mish anticline is about $4.879 \mathrm{wt} \%$, while for Gachsaran oil field, it is estimated at 0.153 (Well. No. 55) and 1.156 (Well. No. 83) wt\%. Absorption of hydrocarbon by rock matrix was also determined. The amount of absorption in Mish anticline is more than that of Gachsaran oil field. This is mostly due to the presence of argillaceous matrix in this area, but the clays have not been successful in absorbing organic matter; this is due to the result obtained from small amount of organic matter in the basin. The Rock-Eval data revealed that the sedimentary paleo-environment strongly affected the source potential of this formation as it changed from the continental and Deltaic in the Mish anticline to deeper marine in Gachsaran oil field. In addition, curves of Burial history were drawn for Gachsaran well No. 55, in order to assess the thermal maturity of the Pabdeh formation. The results of the methods indicated that Pabdeh formation in Gachsaran oil field had a good to very good hydrocarbon potential and had entered to oil window.
\end{abstract}

\section{Keywords}

Rock-Eval Pyrolysis, Pabdeh Formation, Basin Modeling, Paleoenvironment, Zagros Basin 


\section{Introduction}

Zagros zone is located in southwest of Iran and this zone is characterized by intense structural depression. Several potential source rock units and reservoir rocks with different geological ages were deposited in this tectonically developed depression making this area as the most prolific region in the Middle East. So far, petroleum potential and thermal modeling of Pabdeh have not been investigated adequately. Therefore, this study is focused on evaluation of petroleum generation potential and thermal history of the Pabdeh Formation in Zagros area. Among all of these petroleum systems (i.e. Paleozoic, Early Jurassic, Mid Jurassic, Lower Cretaceous and Mid Cretaceous-Early Miocene petroleum systems), the Mid Cretaceous-Early Miocene is the most important one for oil generation in Iran [1]. Pabdeh Formation is one of the most important source rocks in the Zagros basin [2]. This source rock is widely investigated in Dezful Embayment which all the researches indicated a poor to good source rock in the area [3]. In this study, which is based on both geochemical analyses and thermal history modeling, potential of Pabdeh Formation in Mish anticline and Gachsaran oil field is evaluated with regard to sedimentary Paleo environment during the Paleocene-Eocene (Figure 1). In addition to potential source rock and maturity, this study tried to give an answer for the ambiguity related to the origin of oil in Tertiary reservoirs of the studied fields. By contrast, limited papers are available on geochemical evaluations of this formation in Dezful embayment [3] [4] [5] [6] [7] and could be mentioned as examples.

\subsection{Geological Background}

Zagros zone is the location of phenomenal hydrocarbon reservoirs and is an area in the world where oil industries are engaged in intense hydrocarbon exploration and production [8]. The study is conducted in Mish anticline and Gachsaran oil field (well No. 55 and 83), in Kohgiluyeh and Boyerahmad Province in south west of Iran. The Mish anticline is located 5 kilometers northeast of Gachsaran city and near Gachsaran oil field (Figure 2). Approximate dimensions of this anticline are $32 \times 7 \mathrm{Km}$, along the general direction of Zagros basin. In the type section, this formation with the thickness of more than $798 \mathrm{~m}$ consists of shale and thin-bedded clay limestones [9]. The overlain of this formation is by the Gurpi and underlain by the Asmari Formation. The boundary between Pabdeh and Gurpi Formation (KTB) is disconformities that determined in some area by breccia or conglomerates and Purple shale and the upper limit is gradational and conformable with Asmari formation [7]. The Pabdeh Formation is a wellknown to source rock that has produced abundant oil in most petroleum fields in Zagros Basin, which stretches from northwest to southwest Iran over hundreds of kilometers. Pabdeh Formation as one of the principal source rocks in Zagros has drawn the attention of most geologists since a long time ago [10].

\subsection{Sedimentary Paleo-Environment}

Pabdeh formation was deposited during a relative sea level rise, in low energy 


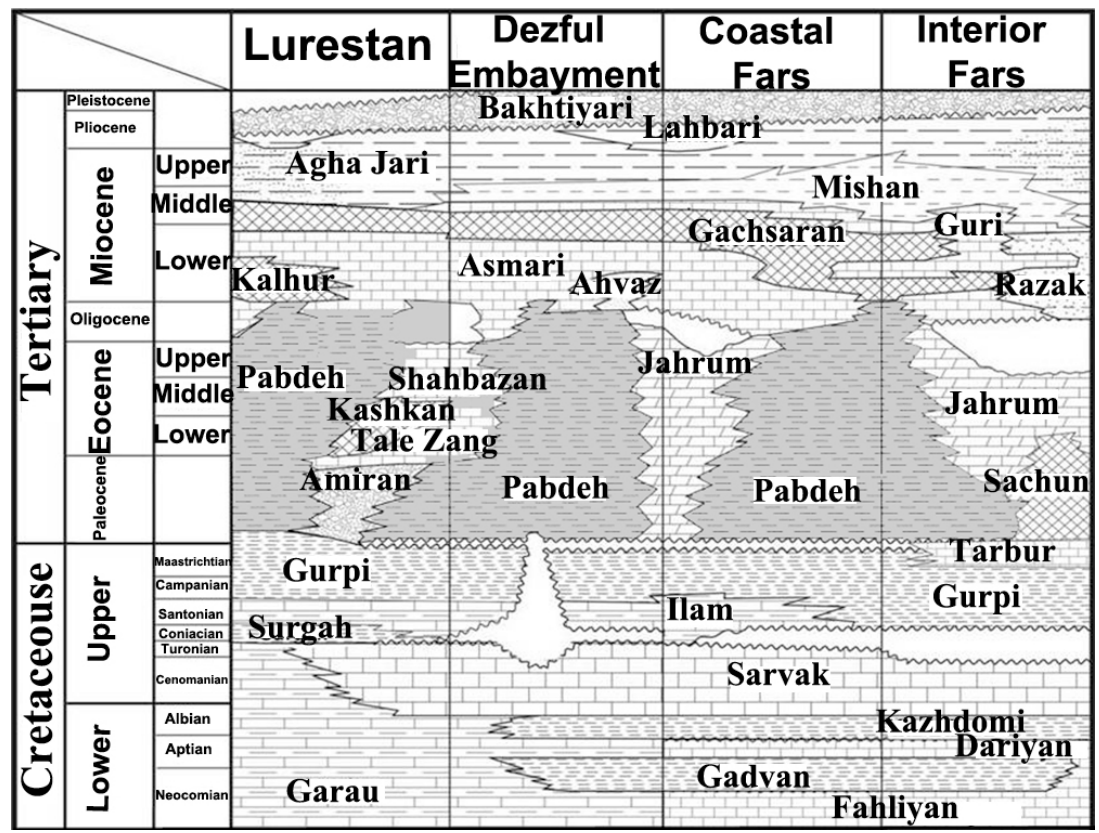

Figure 1. Mesozoic-Cenozoic stratigraphic correlation chart of the Zagros Basin, Iran [11].

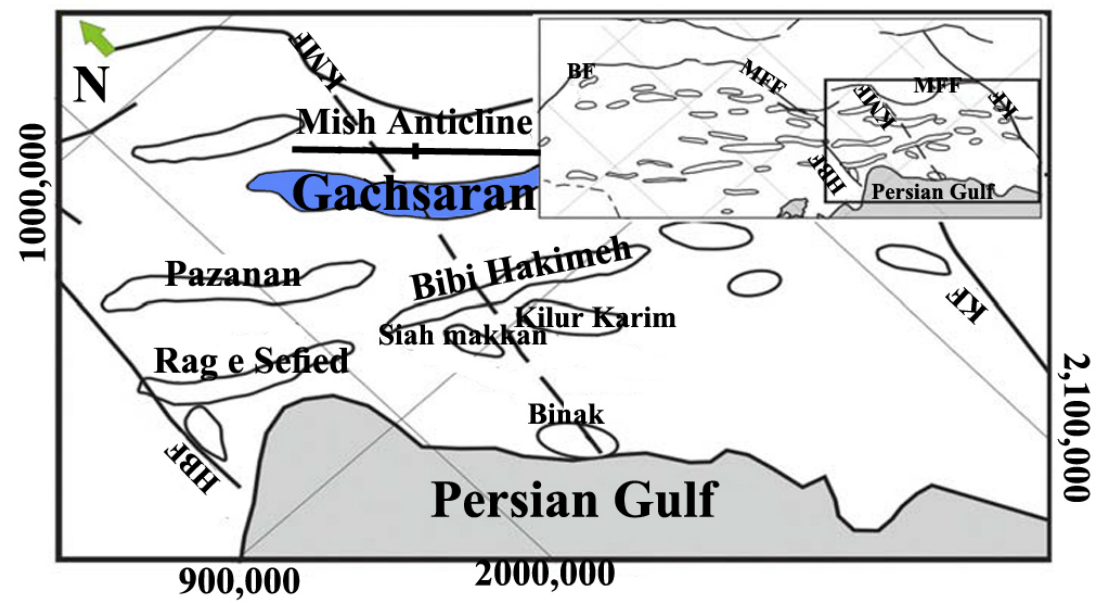

Figure 2. Located of Gachsaran oil field in Dezful embayment, near the other oil fields, Southwest of Iran.

environments and act as a regional source of hydrocarbons mainly in the Zagros basin in Southwestern of Iran [8].

Pabdeh formation in several field sections show fine grained dark grey marls of a mainly algal Kerogen type with limited terrestrial organic matter, as demonstrated by the presence of angiosperm pollen and herbaceous debris [12]. These marls include pelagic fauna such as Globigerina and Rotalids. Benthic fossils were absent, probably due to the anoxic conditions at the sea bottom [13]. Both of this Formation is involved among major source of rocks in Zagros sedimentary basin [14]. The tectonic structure in region is towards Northwest-Southeast, which is consistent with general direction of Zagros basin. This area is a part of folded Zagros Zone. 


\section{Geochemical Analyses}

Rock-Eval pyrolysis is a well appreciated method which is routinely used in rock source studies [15], especially in measuring TOC content. In this method we tried to artificially resemble organic matter maturation, a small aliquot of powdered sample $(100 \mathrm{mg})$ which is heated during a programmed heating temperature (in a pyrolysis oven) in an inert atmosphere (helium). Parameters acquired from this analysis are as follow [15]:

S1: indicates the amount of free hydrocarbons evaporated in a temperature about $300^{\circ} \mathrm{C}$, and is determined by unit of per mg hydrocarbon in per gram of stone (mg HC/g Rock). S2: indicates the amount of hydrocarbon and oxygen rich compounds that release in a temperature about $300^{\circ} \mathrm{C}$ to $650^{\circ} \mathrm{C}$ due to thermal cracking of Kerogen and heavier compounds such as resin and Asphaltene compounds. $S_{2}$ Peak is, In fact, the available potential in stone sample which is determined by the unit of ( $\mathrm{mg} \mathrm{HC/g} \mathrm{Rock)} \mathrm{in} \mathrm{per} \mathrm{gram} \mathrm{of} \mathrm{Rock.} \mathrm{TOC:} \mathrm{indi-}$ cates total organic carbon in samples. Tmax: Is the temperature in which $\mathrm{S}_{2}$ Peak shows its most amount, in the meantime, using above mentioned parameters, a series of indexes such as hydrogen Oxygen Index (OI): ( $\left.\mathrm{S}_{3} / \mathrm{TOC}\right)$. Hydrogen Index (HI): Is the ratio of $\left(\mathrm{S}_{2} / \mathrm{TOC}\right)$. Index of hydrocarbon generation potential: PI $\left(\mathrm{S}_{1} / \mathrm{S}_{1}+\mathrm{S}_{2}\right)$ in studied samples could be examined.

In order to evaluate the hydrocarbon generation potential of the Pabdeh Formation in Mish anticline and Gachsaran oil field, totally 21 samples were analyzed using the Rock-Eval 6 instrument in the petroleum laboratory of the Shahid Chamran University, and the results are presented in Table 1.

\section{Burial and Thermal Modeling History}

Burial history modeling analyses the cumulative subsidence of selected chronostratigraphic horizons encountered in a well [4] [5].

Data required for basin modeling includes the well data, depths and the formation tops, base or thickness and ages of the rock units [16] [17]; the lithology of each unit; the water depth for each formation at the time of deposition; the bottom-hole and/or formation temperatures; and the kerogen type and measured maturity values (Ro and Tmax) [4]. In this study, we used Pars Basin Modeler (PBM) software which calculates the maturity of organic matter using both the Lopatin Time Temperature Index (TTI) model and kinetic approach, such as easy Ro\% algorithm [18]. Maturity is commonly displayed on burial history diagrams by showing the position of the oil window through time [16] [19] [20]. Well reports and lithostratigraphic descriptions were used as input data for the conceptual model of each well. To calibrate the numerical models, Rock-Eval $\mathrm{T}_{\max }$ values resulted from Rock-Eval pyrolysis was used.

\section{Discussion}

Diagram $S_{1}$ vs. TOC used to assure that sample is not combined with hydrocarbon matters (due to transformation of oil towards upper units) and adverse effect on results of pyrolysis of Rock-Eval system [3]. Accordingly, available hy- 
Table 1. Pyrolysis data for the studied cutting samples from Pabdeh Formation wells 55 and 83, in Gachsaran oil field (Gs) and Mish anticline (Mish).

\begin{tabular}{|c|c|c|c|c|c|c|c|}
\hline Well No. & $\begin{array}{l}\text { TOC } \\
\mathrm{Wt} \%\end{array}$ & $\mathrm{HI}$ & $\mathrm{T}_{\text {max }}{ }^{\circ} \mathrm{C}$ & $\begin{array}{c}\mathrm{S}_{2} \mathrm{mg} \mathrm{HC} / \mathrm{g} \\
\text { Rock }\end{array}$ & $\begin{array}{c}\mathrm{S}_{1} \mathrm{mg} \mathrm{HC} / \mathrm{g} \\
\text { Rock }\end{array}$ & PI & $S_{1}+S_{2}$ \\
\hline Gs55 & 0.96 & 407.2 & 436 & 3.91 & 1.7 & 0.3 & 5.61 \\
\hline Gs55 & 1 & 354 & 437 & 3.54 & 1.49 & 0.296 & 5.03 \\
\hline Gs55 & 1.82 & 374.1 & 435 & 6.81 & 1.44 & 0.174 & 8.25 \\
\hline Gs55 & 3.43 & 377.2 & 437 & 12.94 & 1.81 & 0.122 & 14.75 \\
\hline Gs55 & 1.88 & 359 & 437 & 6.75 & 1.2 & 0.13 & 8.95 \\
\hline Gs55 & 2.69 & 384.3 & 440 & 10.34 & 1.27 & 0.11 & 11.61 \\
\hline Gs55 & 1.99 & 359.7 & 438 & 7.16 & 1.41 & 0.164 & 8.57 \\
\hline Gs55 & 2.1 & 376.6 & 440 & 7.91 & 1.63 & 0.17 & 9.54 \\
\hline Gs83 & 0.59 & 254.2 & 436 & 1.5 & 1.2 & 0.44 & 2.7 \\
\hline Gs83 & 2.29 & 373.3 & 436 & 8.55 & 1.57 & 0.155 & 10.12 \\
\hline Gs83 & 2.4 & 270.8 & 437 & 6.5 & 2.39 & 0.268 & 8.89 \\
\hline Mish. 1 & 0.4 & 105 & 434 & 0.42 & 0.39 & 0.48 & 0.81 \\
\hline Mish. 2 & 0.48 & 79.1 & 438 & 0.38 & 0.42 & 0.525 & 0.8 \\
\hline Mish. 3 & 0.39 & 79.4 & 426 & 0.31 & 0.06 & 0.16 & 0.37 \\
\hline Mish. 4 & 0.57 & 277.1 & 431 & 1.58 & 0.22 & 0.12 & 1.8 \\
\hline Mish. 5 & 0.59 & 123.7 & 440 & 0.73 & 0.14 & 0.16 & 0.87 \\
\hline Mish. 6 & 0.51 & 45 & 429 & 0.23 & 0.13 & 0.36 & 0.36 \\
\hline Mish. 7 & 0.41 & 251.2 & 393 & 1.03 & 0.16 & 0.13 & 1.19 \\
\hline Mish. 8 & 0.36 & 197.2 & 431 & 0.71 & 0.11 & 0.13 & 0.82 \\
\hline Mish. 9 & 0.43 & 211.6 & 435 & 0.91 & 0.53 & 0.37 & 1.44 \\
\hline Mish. 10 & 0.35 & 77.1 & 425 & 0.27 & 0.23 & 0.46 & 0.5 \\
\hline
\end{tabular}

drocarbon in samples is indigenous hydrocarbons and interpretable type (Figure 3). In order to determine the abundance and quality of organic matter, different kind of diagrams generated using parameters accrued from rock-Eval pyrolysis which $\mathrm{HI}^{-} \mathrm{T}_{\max }$ [21] and $\mathrm{S}_{2}$-TOC [22] diagrams are rendered as examples.

Type of organic matter was specified with the aid of hydrogen index (HI) Versus $\mathrm{T}_{\max }$ (Figure 4(a)) [23], the kerogen type of Pabdeh formation in Gachsaran oil field is type II, while, kerogen mainly found in Mish anticline is type III. Changes in Kerogen of Pabdeh formation might be as a result of combination of land and marine sediments, and condition of sedimentation. The best condition of rock sources of this basin has been deposited in an anoxic condition in global sea level rise through Intra-shelf basin. At this time, the anoxic condition was spreaded in various regions of basin for a long time. Determination of oil potential of sedimentary rock base on remaining hydrocarbon potential versus total organic carbon is one of the specific ways. The samples which their value of $\left(\mathrm{S}_{2}\right)$ was more than $5 \mathrm{mg} \mathrm{Hc/g}$ Rock, has good potential and samples 
with the value of more than $15 \mathrm{mg} \mathrm{Hc} / \mathrm{g}$ Rock or above, has a good to excellent potential [24], based on samples of Pabdeh formation, this is placed in a good to very good potential for Gachsaran oil field, and this value for Mish anticline ranged in poor to fair (Figure 4(b)). Situational difference in both of these areas can be due to accumulation of organic matters, type of kerogen and better preserving conditions in Gachsaran oil field than in Mish anticline.

According to these results, the Pabdeh Formation can be regarded as a rock source in the Gachsaran oil field which is rich with type II oil producing organic matters that is entered in to oil windows has limited organic matter (mainly type III gas prone) in the Mish anticline which could not produce valuable amount of hydrocarbon even after maturation (Figure 5). Two different trends were observed in the cross plot of $S_{1}$ vs. $S_{2}$ (Figure 6). Generally, field outcropped of Mish anticline shows a steeper slope compared to that of Gachsaran samples which can be attributed to the compositional differences in organic materials.

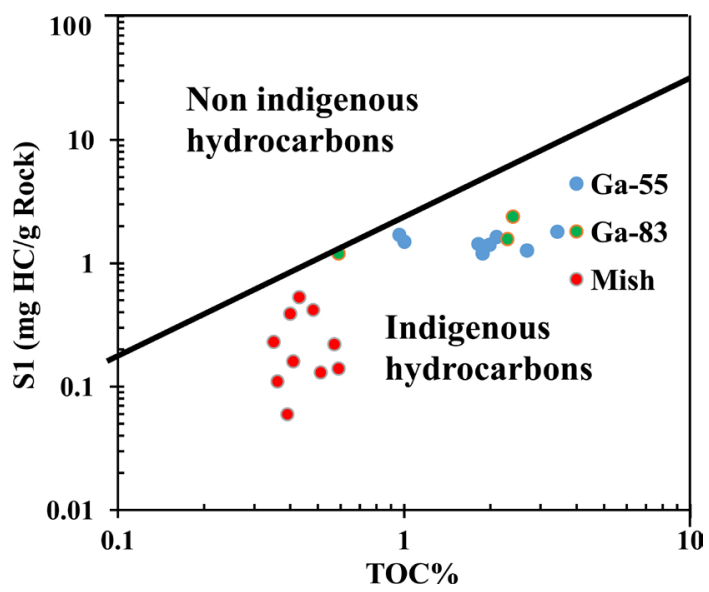

Figure 3. Diagram $S_{1}$ vs. TOC is indicator of lack of pollution of studied samples and stability of generated hydrocarbons.

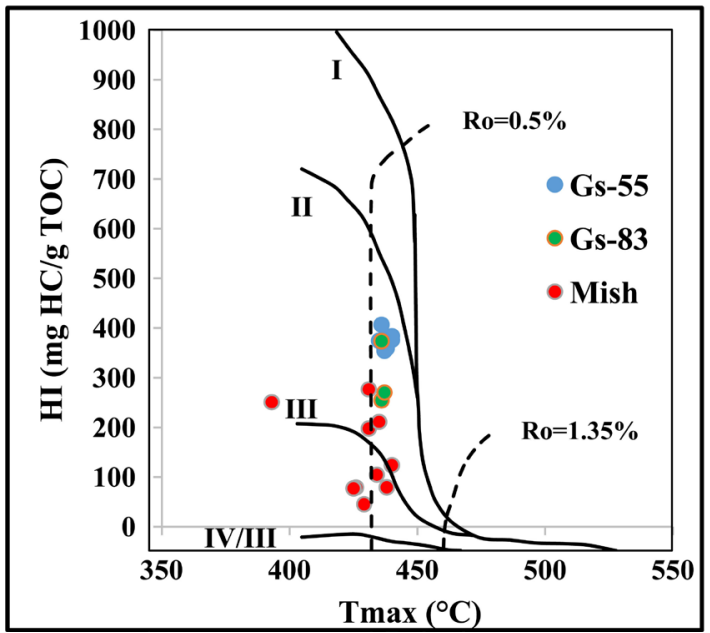

(a)

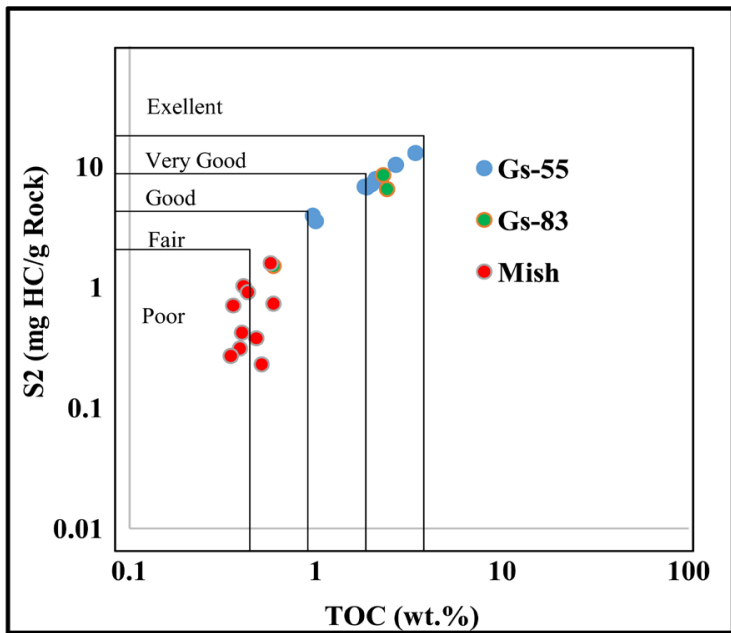

(b)

Figure 4. HI- $\mathrm{T}_{\max }$ plot for determination of the Kerogen type and maturity (Left) and $\mathrm{S}_{2}$-TOC diagram for HC potential determination (Right) of the analyzed samples from Pabdeh Formation in the Gachsaran oil field (Gs) and Mish Anticline (Mish). 


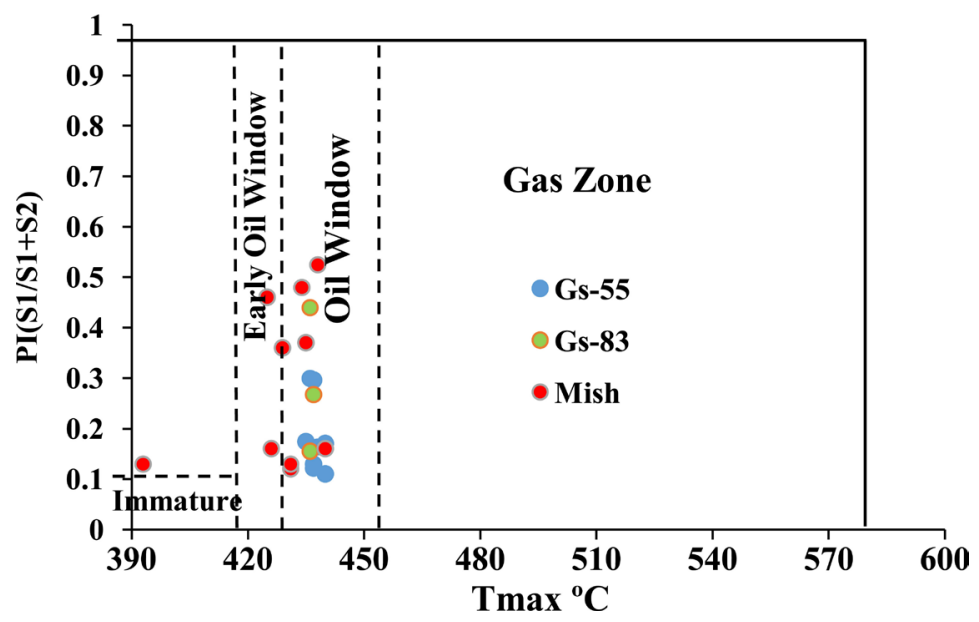

Figure 5. Production Index (PI) vs. $\mathrm{T}_{\max }$ for Pabdeh formation in Mish anticline and Gachsaran oil field.

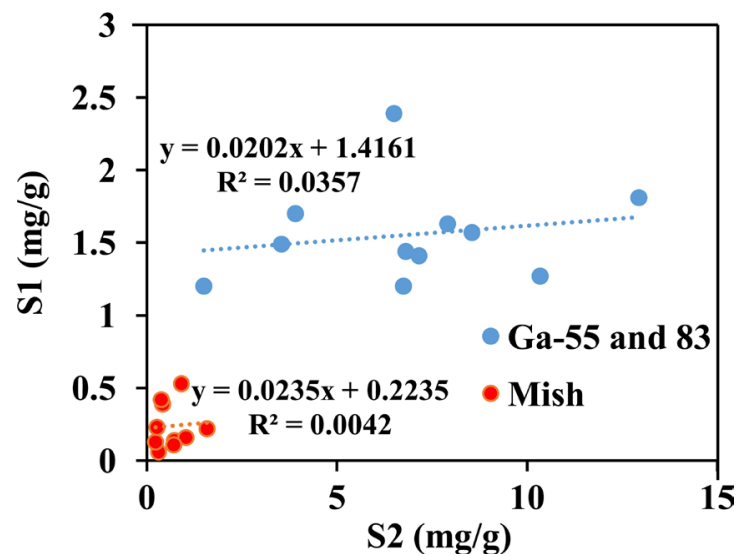

Figure 6. Correlation between $S_{1}$ and $S_{2}$ of samples studied. Two linear trends with positive slope can be observed; orange line and blue line were drawn from Mish samples and Gachsaran samples, respectively.

Changes of TOC Versus HI illustrate the regressive and transgressive of sea level change [25]. It indicates that organic matters preserve in anoxic conditions. A variable range of Pabdeh formation in Gachsaran oil field show decrease in oxygen and transgressive condition in this formation, which is due to variability of environment conditions during deposition of this formation, tectonic and fault effect, while Pabdeh formation in Mish anticline show an increase in oxygen of sea water and regressive condition (Figure 7).

Inert carbon is part of the carbon in the rocks. This carbon does not have any role in hydrocarbon generation potential, and is achieved by precise evaluation of organic carbon with capability of generating hydrocarbon [26]. Presence of Inert organic matter has an effective role in deviation of regression line from the origin of coordinates. This material disintegrates during pyrolysis, and with this diagram it can be recognized. Intersection of this line with vertical axis (TOC) for Pabdeh formation represents availability of Inert carbon among them (Figure 8). Accordingly, most carbon content of Mish anticline (4.879) is inert carbon (Table 2). 


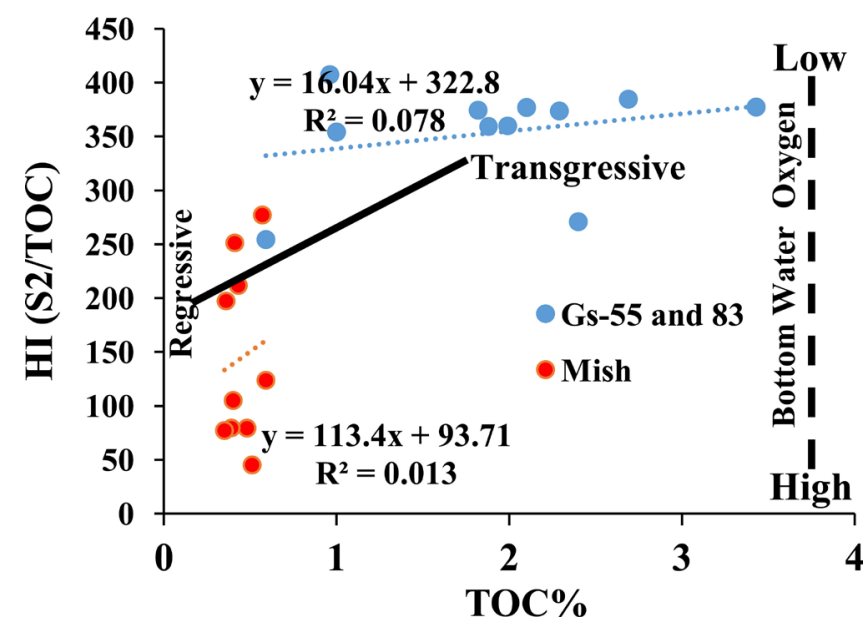

Figure 7. Diagram of amounts of TOC vs. HI in order to recognize sedimentation conditions.

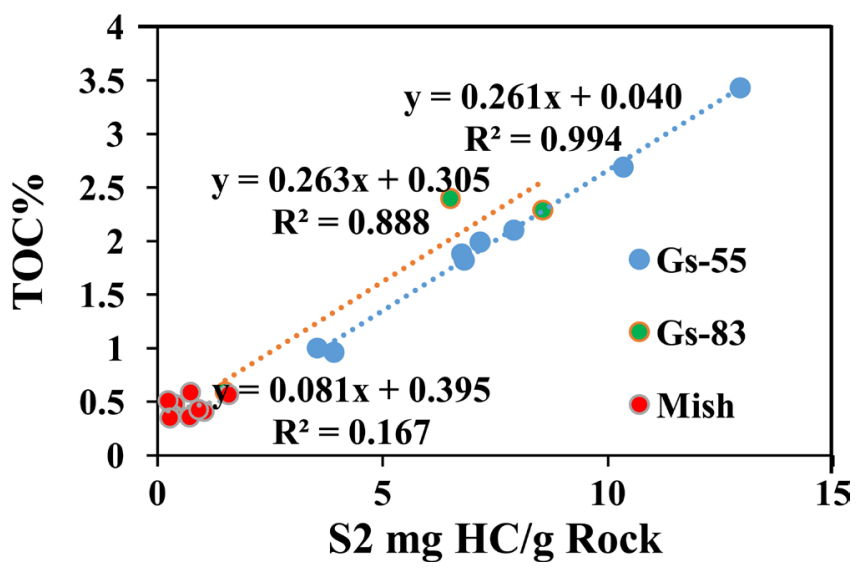

Figure 8. Calculating the inter carbon in Pabdeh formation for Gachsaran oil field and Mish anticline.

Table 2. Regression equations of Pabdeh formation and their parameters in Gachsaran oil field and Mish anticline.

\begin{tabular}{cccc}
\hline Inert Carbon & $\mathrm{R}^{2}$ & Equation $\mathrm{S}_{2}$ vs. TOC & Sample \\
\hline 0.153 & 0.9944 & $\mathrm{y}=0.2619 \mathrm{x}+0.0402$ & Gs55 \\
1.156 & 0.8883 & $\mathrm{y}=0.2637 \mathrm{x}+0.3051$ & Gs83 \\
4.879 & 0.1675 & $\mathrm{y}=0.0811 \mathrm{x}+0.3957$ & Mish \\
\hline
\end{tabular}

In the Zagros Basin, Pabdeh Formation, has precipitated during global rise of sea level in Inter-shelf basin, due to presence of clay minerals and anoxic conditions. The main reason for absorption of organic matters in the rocks can be clay minerals. The effect of matrix in positive direction of $\mathrm{X}$ axis is determined, and amount of this criterion intersection for absorption of hydrocarbon (Figure 9). Accordingly to Table 3, regression lines for Pabdeh formation is toward positive direction of $\mathrm{X}$ axis, indicating hydrocarbon absorption by matrix of rock source among them, and this value for Gachsaran Well No. 55 is 0.029, Gachsaran Well No. 83 is 0.122 and for Mish anticline is 0.131 . Pabdeh formation in Mish anti- 


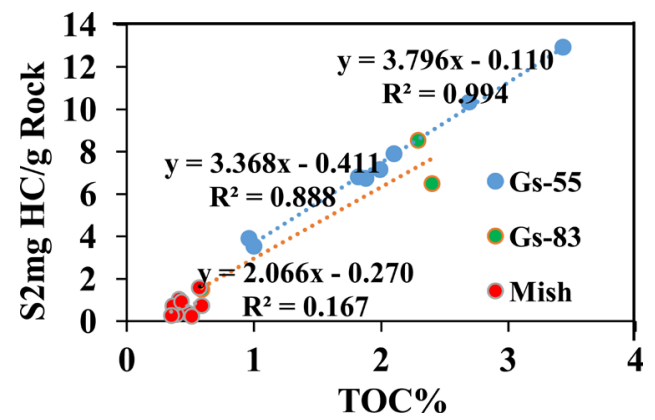

Figure 9. Diagram of calculating amount of hydrocarbon absorption in source rock for Pabdeh formation in Gachsaran oil field and Mish anticline.

Table 3. Regression equations of Pabdeh formation and their parameters in Gachsaran oil field and Mish anticline.

\begin{tabular}{cccc}
\hline Effect of matrix & $\mathrm{R}^{2}$ & Equation TOC vs. $\mathrm{S}_{2}$ & Sample \\
0.029 & 0.9944 & $\mathrm{y}=3.7962 \mathrm{x}-0.1108$ & Gs55 \\
0.122 & 0.8883 & $\mathrm{y}=3.3682 \mathrm{x}-0.4114$ & Gs83 \\
0.131 & 0.1675 & $\mathrm{y}=2.0663 \mathrm{x}-0.2708$ & Mish \\
\hline
\end{tabular}

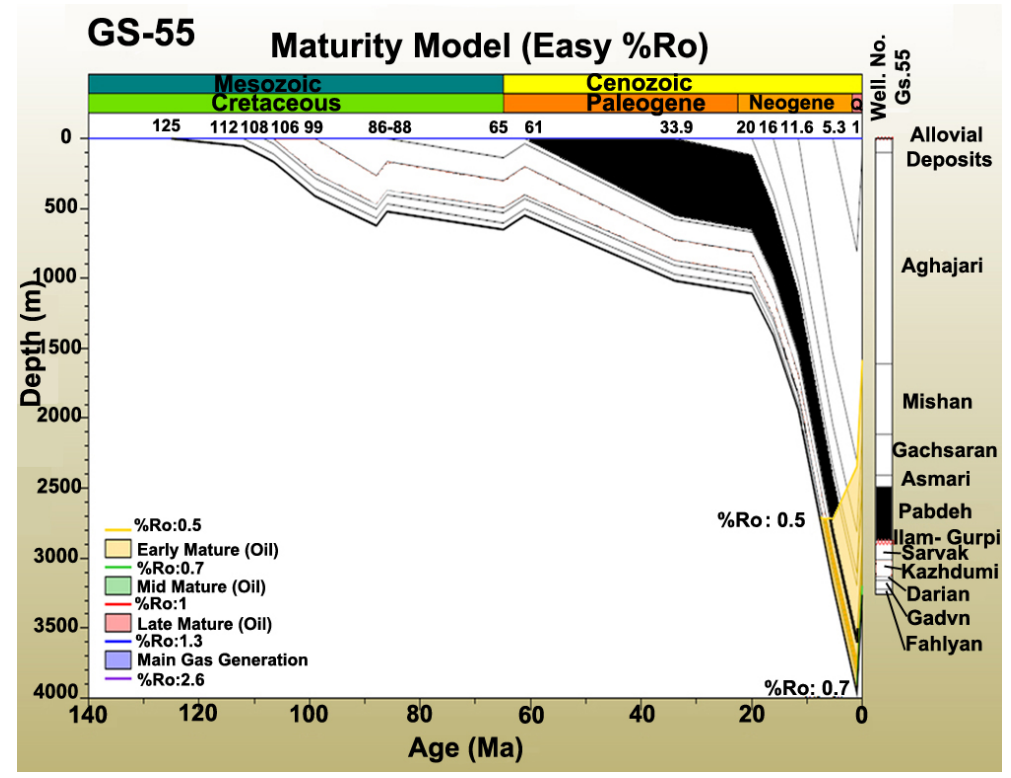

Figure 10. Burial history curves demonstrating oil and gas generation window for organic facies of Pabdeh Formation in well Gs55 using Vitrinite Reflectance (\%Ro) as thermal maturity index.

cline consists of more clay than Pabdeh formation in Gachsaran oil field, due to lithological conditions, but it does not consist a lot more organic matters, this could be due to the depositional environment, and presence of continental detritus clays and organic matters in type III.

The reconstructed burial histories of the study well Gs55 is shown in Figure 10. Based on the basin modeling results for Well No. 55, Pabdeh shale interval is entered into the oil window in this oil field (Figure 10). According to modeling results (Figure 10), the Pabdeh Formation in Gs55 was situated in peak oil gen- 
eration window. Maturity of the Pabdeh Formation seems to be closely related to present-day burial depth and heat flow values. Therefore, where the PaleoceneEocene Pabdeh source rock in deep anticlines and synclines is present (in Gachsaran oil field), it reached maturity stage and expelled hydrocarbon. Hence, the expelled hydrocarbons could charge the existing traps through vertical and lateral migration.

\section{Conclusion}

Burial history curves were drawn for well No. 55, in order to assess the thermal maturity of the Pabdeh Formation in the Gachsaran oil field. The results indicated that the Pabdeh Formation was clearly more mature in the Gachsaran oil field. Also Rock Eval pyrolysis results revealed that Gachsaran oil field had fair to very good hydrocarbon potential with dominant type II kerogen which could be evaluated as effective rock source in this field, while it had poor to fair hydrocarbon potential in the Mish anticline with type III Kerogen and could produce ignorable hydrocarbons when matured. The results of this study in addition to evaluation of rock source quality of Pabdeh formation confirm previous researches saying that there was an influx of clastics during the Paleocene-Eocene following emergence and erosion of semi deep-water of Masstrichtian marl. The sedimentary paleo environment strongly affected the source potential of this formation in the study area as it changed from the continental and Deltaic in the Mish anticline to deeper marine in the Gachsaran oil field.

\section{Acknowledgements}

The present paper is a part of research project granted by Research Section of Islamic Azad University, Gachsaran Branch. I have to express herewith my thanks to Islamic Azad University, Gachsaran Branch and all our colleagues for critical discussions and support. Thanks also to the anonymous referees for all their gracious and critical points.

\section{References}

[1] Sfidari, E., Zamanzadeh, S.M., Dashti, A. and Tavakkol, M.H. (2016) Comprehensive Source Rock Evaluation of the Kazhdumi Formation, in the Iranian Zagros Foldbelt and Adjacent Offshore. Marine and Petroleum Geology, 71, 26-40. https://doi.org/10.1016/j.marpetgeo.2015.12.011

[2] Opera, A., Alizadeh, B., Sarafdokht, H., Janbaz, M., Fouladvand, R. and Heidarifard, M.H. (2013) Burial History Reconstruction and Thermal Maturity Modeling for the Middle Cretaceous Early Miocene Petroleum System, Southern Dezful Embayment. International Journal of Coal Geology, 120, 1e14.

[3] Fakhri, M., Tabatabaei, H. and Amiri, A. (2013) Comparing the Potential of Hydrocarbon Generation of Kazhdomi and Pabdeh Formations in Bangestan Anticline (Zagros Basin) According to Rock-Eval Pyrolysis Data. Journal of Earth Science \& Climatic Change, 4, 5. https://doi.org/10.4172/2157-7617.1000157

[4] Kamali, M.R. and Rezaee, M.R. (2003) Burial History Reconstruction and Thermal Modeling at KuhMond, SWIran. Journal of Petroleum Geology, 26, 415-464. https://doi.org/10.1111/j.1747-5457.2003.tb00038.x 
[5] Kamali, M.R., FathiMobarakabad, A. and Mohsenian, E. (2006) Petroleum Geochemistry and Thermal Modeling of Pabdeh Formation in Dezful Embayment. JUST, 32, 1-11.

[6] Rahmani, O., Aali, J., Mohseni, H., Rahimpour-Bonab, H. and Zalaghaie, S. (2010) Organic Geochemistry of Gadvan and Kazhdumi formations (Cretaceous) in South Pars Field, Persian Gulf, Iran. Journal of Petroleum Science and Engineering, 70, 57-66. https://doi.org/10.1016/j.petrol.2009.09.009

[7] Tabatabaei, H., Motamed, A., Solimani, B. and Kamali, M.R. (2012) Geochemistry of Gurpi-Pabdeh-Asmari Formations and Its Implication on Chemical Variation during Deposition of Pabdeh Formation, Zagros Basin. Himalayan Geology, 33, 126-138.

[8] Ghazban, F. (2007) Petroleum Geology of the Persian Gulf. University of Tehran Press, Tehran, 707.

[9] Bahrami, M. (2009) Microfacies and Sedimentary Environments of Gurpi and Pabdeh Formations in Southwest of Iran. American Journal of Applied Sciences, 6 1295-1300. https://doi.org/10.3844/ajassp.2009.1295.1300

[10] Mirzaee, M.R., Afghah, M. and Saeedi, S. (2010) High Resolution Sequence Stratigraphy and Depositional Environment of Pabdeh Formation in Dashte-Arjan Area (Shiraz, Fars, Zagros, Iran). World Academy of Science, Engineering and Technology, 71, 922-926.

[11] Sepehr, M. and Cosgrove, J.W. (2004) Structural Framework of the Zagros FoldThrust Belt, Iran. Marine and Petroleum Geology, 21, 829-843. https://doi.org/10.1016/j.marpetgeo.2003.07.006

[12] Darvishzadeh, A. (1992) Geology of Iran. Neda Publication, Tehran.

[13] Agahanabati, A. (2005) Iran Geology Geology and Mine Exploration Organization, Tehran, 586.

[14] Moteei, H. (1998) Iran Geology, Strati Graphology of Zagros. Geology and Mine Exploration Organization, Geological Survey and Mineral Exploration of Iran, 247-251.

[15] Behar, F., Beaumont, V. and De Penteado, B. (2001) Rock-Eval 6 Technology: Performances and Developments. Oil \& Gas Science and Technology, 56,111-134. https://doi.org/10.2516/ogst:2001013

[16] Waples, D.W. (1985) Predicting Thermal Maturity in Geochemistry. In: Petroleum Exploration, International Human Resources Development Corporation, Boston.

[17] Waples, D.W., Kamata, H. and Suizu, M. (1992) The Art of Maturity Modeling, Part 1: Finding a Satisfactory Geologic Model. AAPG Bulletin, 76, 31-46.

[18] Sweeney, J.J. and Burnham, A.K. (1990) Evaluation of a Simple Model of Vitrinite Reflectance Based on Chemical Kinetics. AAPG Bulletin, 74, 1559-1570.

[19] Lopatin, N.V. (1971) Temperature and Geologic Time as a Factor in Coalification. Serya Geologickeskya, 3, 95-106.

[20] Waples, D.W. (1980) Time and Temperature in Petroleum Generation-Application of Lopatin's Technique to Petroleum Exploration. AAPG Bulletin, 64, 916-926.

[21] Hunt, J.M. (1996) Petroleum Geochemistry and Geology. 2nd Edition, W.H. Freeman, San Francisco.

[22] Shaaban, F., Lutz, R., Littke, R., Bueker, C. and Odisho, K. (2006) Source Rock Modeling and Basin Modelling in Egypt (NE Nile Delta and Northern Sinai). Journal of Petroleum Geology, 29, 103-124.

https://doi.org/10.1111/j.1747-5457.2006.00103.x 
[23] Espitalie, J., Deroo, G. and Marquis, F. (1985) La Pyrolysis Rock-Eval Etses Applications. Oil and Gas Science and Technology (OGST), Revue d'IFP, Part I, 40, pp. 563-578, Part II, 40, pp. 755-784, Part III, 41, pp. 73-89.

[24] Peters, K.E. (1986) Guidelines for Evaluating Petroleum Source Rocks Using Programmed Pyrolysis. American Association of Petroleum Geologists, 70, 318-329.

[25] Dean, W.E., Arthur, M.A. and Claypool, G.E. (1986) Depletion of 13C in Cretaceous Marine Organic Matter: Source, Digenetic, or Environmental Signal. Marine Geology, 70, 119-157. https://doi.org/10.1016/0025-3227(86)90092-7

[26] Dahl, B., Bojesen-Koefoed, J., Holm, A., Justwan, H., Rasmussen, E. and Thomsen, E. (2004) A New Approach to Interpreting Rock-Eval S2 and TOC Data for Kerogen Quality Assessment. Organic Geochemistry, 35, 1461-1477. https://doi.org/10.1016/j.orggeochem.2004.07.003

Submit or recommend next manuscript to SCIRP and we will provide best service for you:

Accepting pre-submission inquiries through Email, Facebook, LinkedIn, Twitter, etc. A wide selection of journals (inclusive of 9 subjects, more than 200 journals)

Providing 24-hour high-quality service

User-friendly online submission system

Fair and swift peer-review system

Efficient typesetting and proofreading procedure

Display of the result of downloads and visits, as well as the number of cited articles

Maximum dissemination of your research work

Submit your manuscript at: http://papersubmission.scirp.org/

Or contact ojg@scirp.org 